\title{
Viewpoint
}

\section{Far reaching potentials of far infrared spectroscopy in catalysis research}

\author{
Huixiang Li, Z. Conrad Zhang*
}

\section{Introduction}

Fourier transform infrared (FTIR) spectroscopy has played an important role in identifying molecular finger prints of reactants, products and intermediates, in elucidating the mechanisms of a broad range of reactions, and in probing the fundamental nature of active sites of many catalysts by both in-situ and ex-situ measurements [1,2]. Specifically, FTIR spectroscopy measures the absorption of chemical bonds or groups in the $10-12500 \mathrm{~cm}^{-1}$ spectral region. The study of FTIR is commonly performed in three spectral segments, near infrared (NIR, 4000-12500 $\mathrm{cm}^{-1}$ ), middle infrared (MIR, 400-4000 $\mathrm{cm}^{-1}$ ), and far infrared (FIR, 10-400 $\mathrm{cm}^{-1}$ ) (Fig. 1). MIR spectroscopy has been well established and most widely applied to study various bonds among $\mathrm{C}, \mathrm{H}, \mathrm{O}, \mathrm{N}, \mathrm{S}, \mathrm{B}, \mathrm{X}$ (halides). MIR application covers a wide range of fields [3-6], including chemicals, food safety, environmental monitoring, materials, etc. The application of MIR in catalysis is relatively mature in following the transformation of chemical bonds and groups involved in reactions and over catalyst surfaces.

However, for structural investigation of chemical bonds involving heavier elements, particularly those in inorganic compounds such as metal oxides or salts, spectroscopy in the MIR and NIR regions is not applicable, because the vibration energies of these bonds fall in the FIR spectral region. Therefore, FIR spectroscopy can be used for the characterization of some inorganic compounds $[7,8]$ and some metal coordination complexes $[9,10]$ that may be catalytically active. FIR in the low spectral energy region has been shown to be well suited to

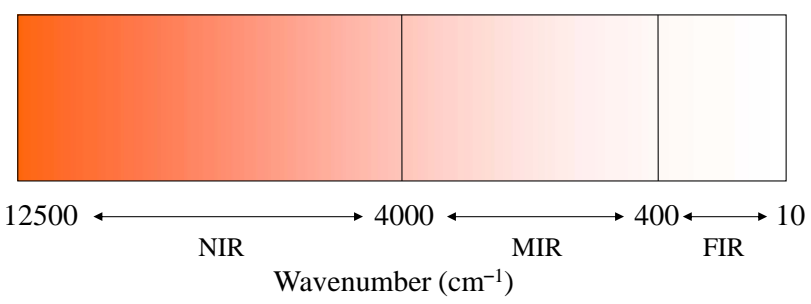

Fig. 1. The regions of infrared spectra. study lattice vibrations [11], hydrogen bonds [12], as well as the skeleton vibration of aromatic molecules [13]. It should be emphasized that FIR remains much under developed and the least applied infrared tool, especially in the study of catalytic mechanisms. This mini review is therefore intended to draw attentions to the potential applications of FIR in catalysis research by discussing some important features of early studies and of some recent literatures. Potential future directions are suggested in the development of FIR for catalysis studies.

\section{FIR characterization of catalyst structures}

Catalysts are commonly categorized according to their physical state in corresponding reaction systems. Homogeneous catalysts refer to those that are fully miscible and disperse molecular level, while heterogeneous catalysts refer to those in which only surfaces contribute to catalytic activity. When organometallic complexes are used as homogeneous catalysts in solvent media in which reactions take place, such complexes and the reactants are both dissolved in the solvents. Although enzymes as catalysts are also homogeneous in aqueous reaction media together with reaction substrates, absorption bands by water in the IR spectral region (both MIR and FIR) is so intense that IR is not a suitable tool for such systems. Inorganic solid catalysts are mostly present as a heterogeneous phase in either liquid or gaseous reaction phase. Bonds among heavier elements, mostly metals in metallic or higher oxidation states often play major roles during catalysis. Techniques such as extended X-ray absorption fine structure (EXAFS), X-ray crystallography, mass spectrometry, nuclear magnetic resonance (NMR), UV-Vis spectroscopy, X-ray powder diffraction (XRD), X-ray photoelectron spectroscopy (XPS) and other specialized methods are often used for characterization of homogeneous catalysts or heterogeneous catalyst $[14,15]$. These techniques have been proven versatile and informative pertaining to obtain critical mechanistic insights on the role of the catalysts in catalyzing reactions of interest. However, it should be noted that some of these tools are only available in specialized laboratories that are not readily accessible to many researchers. 
Even though FIR has not been widely applied as a catalyst characterization tool, like other IR tools, it is simple to operate, and is suited for the characterization of a wide variety of solid catalysts and organometallic complexes. As an underdeveloped spectroscopic tool, FIR offers the potentials to become a low-cost technology to provide structural information related to catalyst functions.

FIR is suited to study organometallic structural configurations. FIR studies of square planar trialkylphosphine complexes of the types cis and trans $\mathrm{MX}_{2} \mathrm{~L}_{2}(\mathrm{M}=\mathrm{Pd}, \mathrm{Pt} ; \mathrm{X}=\mathrm{Cl}, \mathrm{Br}, \mathrm{I} ; \mathrm{L}=$ $\left.\mathrm{Me}_{3} \mathrm{P}, \mathrm{Et}_{3} \mathrm{P}\right)$ have shown that metal-phosphorus stretching frequencies $v(\mathrm{M}-\mathrm{P})$ occur in the narrow range 400-440 $\mathrm{cm}^{-1}[16]$. Metal-halogen $v(\mathrm{M}-\mathrm{X})$ frequencies however, are found in a wider frequency range and are markedly dependent on the cis or trans geometry of the complex [17]. Boorman et al. [18] studied tetrahedral and square planar adducts of nickel (II) halides with tertiary phosphines and di-phosphines with FIR. Correlations of $v(\mathrm{Ni}-\mathrm{X})$ and $v(\mathrm{Ni}-\mathrm{P})$ with stereo-chemistry indicate that FIR is a useful technique to distinguish tetrahedral from cis or trans square planar complexes.

Metal clusters consisting of several metal atoms show spectra unique for each cluster size and exhibit fingerprints of the cluster's structure [19-21]. Fielicke et al investigated the FIR spectra of neutral and cationic niobium clusters of $\mathrm{Nb}_{5} \mathrm{O} /+$ to $\mathrm{Nb}_{9}{ }^{0 /+}$. The experimental spectra were recorded in the 85-600 $\mathrm{cm}^{-1}$ region that covered the structure-specific vibrational finger-print range for these metal clusters. A comparison of the experimental and calculated Far-IR spectra allows for the identification of the cluster structures. The comparison with theory revealed that the overall geometries for the cations and neutrals are very similar [21].

Important to heterogeneous catalysts, FIR was shown to be able to differentiate structures of solid state catalysts [22-24]. For examples, the alumina phases, boehmite, diaspore, gibbsite and bayerite, can be distinguished by FIR spectroscopy because the low-frequency modes of FIR are generally the most sensitive to the changes of $\mathrm{AlO}_{4}$ units. Boehmite has two characteristic FIR bands at 366 and $323 \mathrm{~cm}^{-1}$, while diaspore has five bonds at 354, 331, 250, 199 and $158 \mathrm{~cm}^{-1}$. Gibbsite shows three characteristic FIR bands at 371, 279 and $246 \mathrm{~cm}^{-1}$, whereas bayerite shows six bonds at 383, 345, 326, 296, 252 and 62 $\mathrm{cm}^{-1}$ [22]. Thus FIR allows for the study and the differentiation of the stretching of $\mathrm{AlO}_{4}$ units to characterize these four alumina phases in bauxites.

Microporous materials, particularly zeolites, are widely used as selective adsorbents for separations and as heterogeneous catalysts for catalytic processes. IR spectroscopy of adsorbed probe molecules is a widely used technique for zeolite characterization [25]. CO is the most frequently used molecule to probe zeolite structural and surface properties by monitoring the variation of its IR absorption wavenumber in reference to that of $\mathrm{CO}$ in gas phase. Otero Areán et al. [26] studied the stretching vibration of weak $\mathrm{M}^{+\cdots} \cdot \mathrm{CO}$ bond ( $\left.\mathrm{M}=\mathrm{Li}, \mathrm{Na}, \mathrm{K}, \mathrm{Rb}, \mathrm{Cs}\right)$ formed upon $\mathrm{CO}$ adsorption in different alkali-metal exchanged zeolites at 77K. As shown in Fig. 2, the wavenumber of the cation-carbon bond vibration $v(\mathrm{M}-\mathrm{C})$ increases linearly with increasing the inverse of the square of the cation radius. The ab-

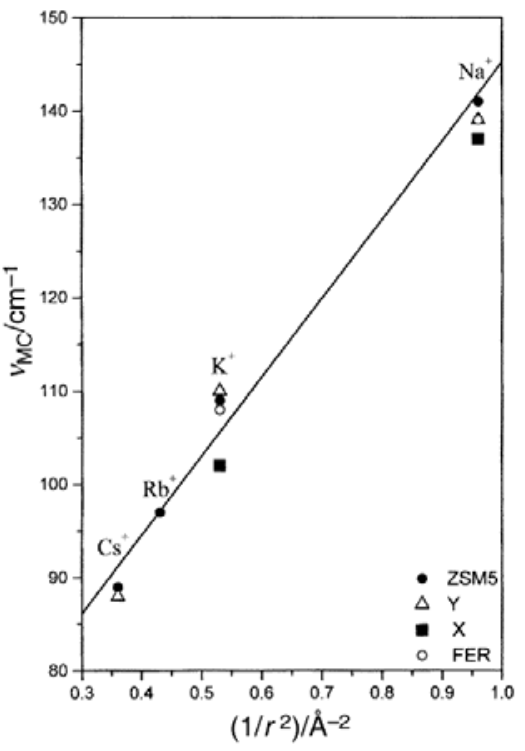

Fig. 2. Plot of the wavenumber of the cation-carbon stretching vibration versus the inverse of the square of the cation radius. Reproduced with permission from Ref. [26].

sorption wavenumber of $\mathrm{CO}$ on an alkali ion does not vary appreciably in different zeolites, such as ZSM-5, Y, X and FER. The largest $\mathrm{Na}-\mathrm{CO}$ vibration wavenumber is $141 \mathrm{~cm}^{-1}$. The high sensitivity of the $v\left(\mathrm{M}^{+}-\mathrm{CO}\right)$ to the metal ions $(\mathrm{M}=\mathrm{Li}, \mathrm{Na}, \mathrm{K}, \mathrm{Rb}$, $\mathrm{Cs}$ ) in the FIR region suggests that it would be possible to quantitatively determine the relative abundance of these metal ions in zeolites.

For CO adsorbed (at $210 \mathrm{~K}$ ) on $\mathrm{ZnO}$, Saussey et al. [27] reported the $v(\mathrm{Zn}-\mathrm{CO})$ fundamental stretching at $215 \mathrm{~cm}^{-1}$. The higher wavenumber of the cation-carbon bond $v(\mathrm{M}-\mathrm{C})$ observed for the $\mathrm{CO} / \mathrm{ZnO}$ system than the $\mathrm{CO} /$ alkali-metal exchanged zeolites can be explained by the stronger $\mathrm{Zn}-\mathrm{CO}$ bond strength due to the higher electric charge density of the $\mathrm{Zn}^{2+}$ ion. Thus FIR spectroscopy of appropriate probe molecules may reveal structural details of surface sites by accurately measuring the low energy modes. Furthermore, Engström and Ryberg [28] compared the vibrational properties of the low-energy modes of a molecular and an atomic adsorbate: CO and 0 on $\mathrm{Pt}(111)$ surface by far infrared spectroscopy. For oxygen atoms an antiabsorption dip associated with the frustrated translation was observed, while in contrast, no such dip was observed for the frustrated rotations of CO. Obviously, MIR, FIR spectroscopies become complementary in studying gas adsorption process in catalysis $[25,26]$. They can be used to study a wide range of energy from 10 to $4000 \mathrm{~cm}^{-1}$ and to track light variations of the molecular vibration of adsorbent interaction with the substrate through the whole adsorption process.

\section{In-situ FIR study in catalysis}

In-situ IR has been widely used for catalyst characterization to gether information about catalyst structure, concentration of reactants, intermediates and products. In-situ FIR could lift, to some extent, limitations in the region of middle infrared spec- 
trum to allow for characterization of some catalytic reactions. For example, MIR only follows the changes in reactants, intermediates and products by monitoring the specific chemical bonds or structures in reactions catalyzed by homogeneous catalysts, while FIR may be suited to study the interactions between the catalysts and the reactants, intermediates and products. The FIR spectroscopy may therefore provide rich information for understanding the catalytic mechanism.

E. g., a considerable number of investigations have been focused on glucose catalytic conversion to 5-hydroxymethylfurfural (5-HMF) [29], a platform chemical that can be converted to various chemicals, biofuels and biomaterials [30].

A considerably large number of publications have appeared that reported results of the reaction mechanism with various analysis techniques [31-33] since the discovery of a new catalytic system (Scheme 1) that enabled the conversion of glucose to 5-HMF [34]. Typical techniques such as NMR, XRD, UV-Vis, MIR are not capable of revealing the catalytic mechanism for this complex system. Most recently, an in-situ FIR spectroscopy tool has been successfully applied to the study of the coordination chemistry of various metal chlorides in an ionic liquid, 1-butyl-3methylimidazolium chloride, or [BMIM]Cl [10].

\subsection{Important factors in FIR analysis}

In-situ FIR spectroscopy has limitations for two reasons. (1) FIR spectroscopy has been recorded with a DTGS/Polyethylene detector, the sensitivity of which is much lower than that of the MIR spectral detector, and (2) the energy of light source is lower in FIR region, so that the spectral noise becomes greater. Furthermore, water vapor in air greatly impacts on the quality of the far-infrared spectra. Water vapor molecule has many rotating absorption peaks in the far infrared region. When the FIR absorption spectrum of the sample is weak, strong moisture absorption makes it difficult to clearly distinguish peaks due to absorption by the sample. Therefore, in measuring in-situ infrared spectroscopy, care must be taken to minimize the impact of water vapor from the absorption spectrum. For a non-vacuum FTIR spectrometer, dry air or nitrogen purge of<smiles>OC[C@H]1O[C@H](O)[C@@H](O)[C@H](O)[C@H]1O</smiles>

Glucose

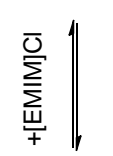<smiles>OC[C@H](O)[C@H](O)C(O)C1=COC(Cl)(Cl)O1</smiles>
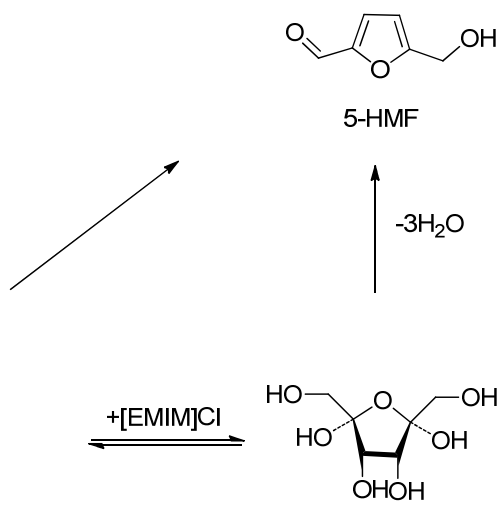

Scheme 1. The proposed pathway of glucose conversion to 5-HMF in 1-ethyl-3-methylimidazole chloride ([EMIM]Cl). Reproduced with permission from Ref. [29]. the optical bench is critically important. In our experience, a customized sample compartment lid provides an efficient protective physical barrier by reducing the impact of ambient air on the samples under investigation. Care must be taken during sample transfer to minimize air exposure. It should be noted that spectral resolution and the water vapor spectrum are directly related. The number of rotational absorption peaks, the peak shape and peak position of water vapor molecules change with the resolution of the measurement: the higher the resolution, the larger the number of water vapor absorption bands is. An $8 \mathrm{~cm}^{-1}$ resolution may be sufficient for the routine study in FIR spectrum. For a small amount of sample, the absorbance measured could be very low. In this case, a resolution of 16 $\mathrm{cm}^{-1}$ could be used [35].

\subsection{In-situ FIR study of the mechanism of metal chlorides catalyzed glucose conversion to 5- $\mathrm{HMF}$}

Four representative metal chlorides, $\mathrm{CrCl}_{3}, \mathrm{VCl}_{3}, \mathrm{PtCl}_{2}$, and $\mathrm{FeCl}_{3}$ were chosen based on their conversion, yield (Fig. 3) for glucose conversion to 5-HMF and studied by in-situ FIR in order to understand the distinctively different performance characteristics of the catalysts in correlation to their coordination chemistries.

Then in-situ FIR spectroscopy was employed to follow the trend of metal-Cl absorption band variation in the complexes in the process of the glucose conversion catalyzed by the metal chlorides in [BMIM] Cl (Figs. 4 and 5).

The dissolved $\mathrm{MCl}_{x}(\mathrm{M}=\mathrm{Cr}, \mathrm{V}, \mathrm{Pt}, \mathrm{Fe} ; x=2,3)$ were found to form new $\mathrm{M}$ complexes in the $\mathrm{MCl}_{x} /[\mathrm{BMIM}] \mathrm{Cl} /$ glucose reaction system under typical reaction conditions, as shown in Fig. 4. The absorbance of $\mathrm{Cr}-\mathrm{Cl}$ band at $302 \mathrm{~cm}^{-1}$ decreased gradually at the beginning (Fig. 4(a)) and then showed a limited restoration (Fig. 5(a)) after an extended period of reaction, due to the consumption of glucose. Meanwhile, the peak intensity of $\mathrm{Cr}-\mathrm{O}$ (from glucose) coordination bond at $497 \mathrm{~cm}^{-1}$ increased gradually (Fig. 4(a)) and then decreased slowly (Fig. 5(b)). Thus the FIR spectra indicate that $\mathrm{Cr}$ (III) center coordinated with glucose first and catalyzed the isomerization of glucose to fructose. In addition, in-situ far-infrared spectra of the $\mathrm{VCl}_{3} /[\mathrm{BMIM}] \mathrm{Cl} /$ glucose system (Fig. 4(b)) indicate that the V-Cl bond absorb-

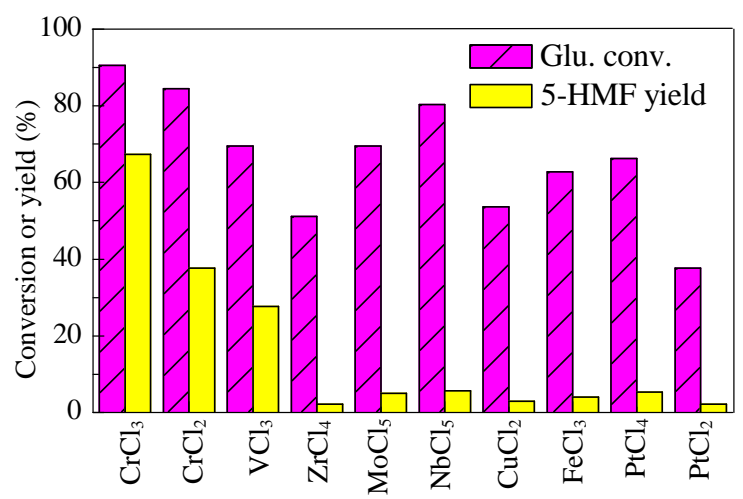

Fig. 3. The catalytic characteristics of metal chlorides for glucose conversion to $5-\mathrm{HMF}$ in $[\mathrm{BMIM}] \mathrm{Cl}$ at $96^{\circ} \mathrm{C}$. Reproduced with permission from Ref. [10]. 

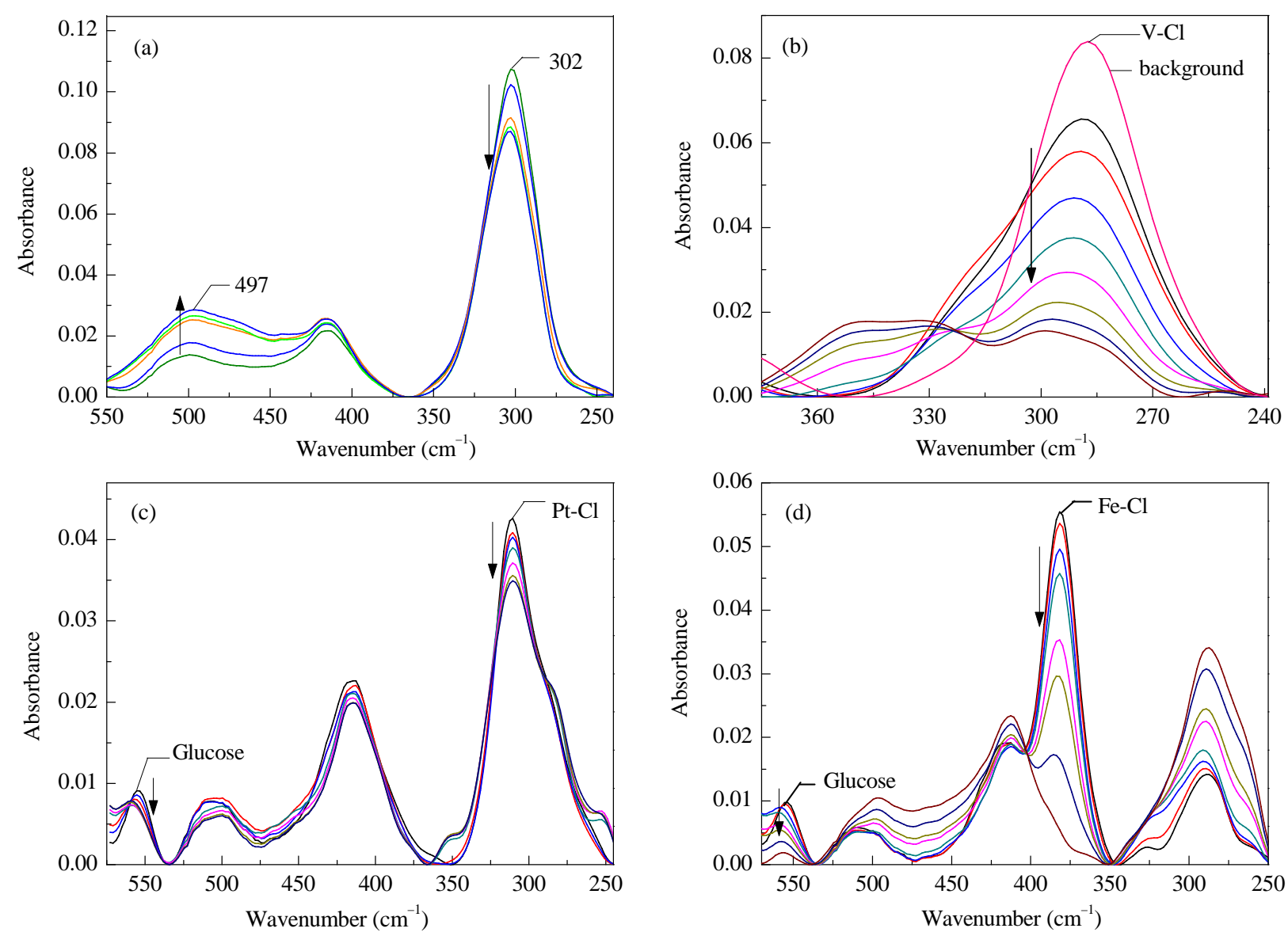

Fig. 4. The FIR spectra of metal chlorides/[BMIM]Cl/glucose recorded at $100{ }^{\circ} \mathrm{C}$. (a) $\mathrm{CrCl}_{3} /[\mathrm{BMIM}] \mathrm{Cl} / \mathrm{glucose}$, about 30 min; (b) $\mathrm{VCl}_{3} /[\mathrm{BMIM}] \mathrm{Cl} /$ glucose, about $60 \mathrm{~min}$; (c) $\mathrm{PtCl}_{2} /[\mathrm{BMIM}] \mathrm{Cl} /$ glucose, about $80 \mathrm{~min}$; (d) $\mathrm{FeCl}_{3} /[\mathrm{BMIM}] \mathrm{Cl} /$ glucose, about 60 min. The arrows indicate that intensity changes with time. Reproduced with permission from Ref. [10].
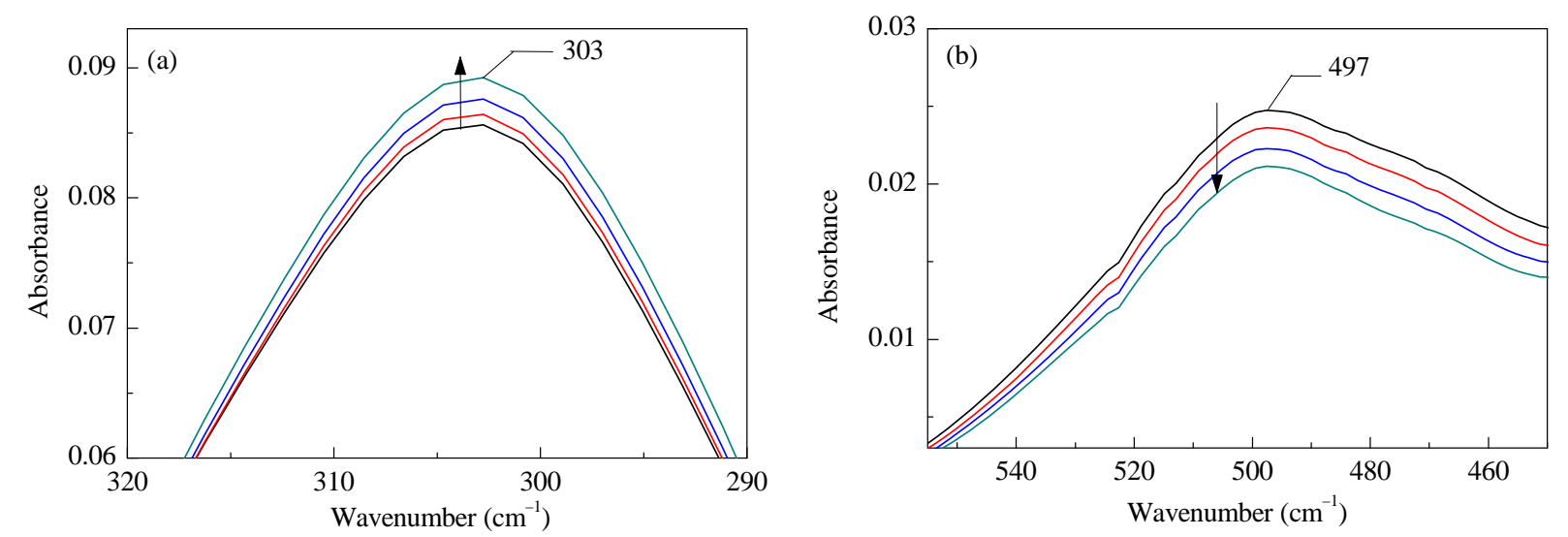

Fig. 5. The trend of the peak absorbance at $303 \mathrm{~cm}^{-1}$ (a) and $497 \mathrm{~cm}^{-1}$ (b) in the $\mathrm{CrCl}_{3} /[\mathrm{BMIM}] \mathrm{Cl} /$ glucose reaction system. The spectra were recorded for $30 \mathrm{~min}$ after the reaction started for $30 \mathrm{~min}$. The arrows indicate that intensity changes with time. Reproduced with permission from Ref. [10].

ance at $287 \mathrm{~cm}^{-1}$ declined much more than the $\mathrm{Cr}-\mathrm{Cl}$ bond absorbance in the $\mathrm{CrCl}_{3} /[\mathrm{BMIM}] \mathrm{Cl} /$ glucose system with time, and with concomitant change in $\mathrm{V}-\mathrm{O}$ bond FIR absorbance. It is possible that the vanadium ion coordinates with more than one glucose molecule, and can coordinate with the oxygen of a carbonyl group and a glycolaldehyde structure at the same time, resulting in increased side reactions dominated by humins. The spectra in Fig. 4(c) show the FIR features of the
$\mathrm{PtCl}_{2} /[\mathrm{BMIM}] \mathrm{Cl} /$ glucose system. Both the glucose absorption peak at $554 \mathrm{~cm}^{-1}$ and the $\mathrm{Pt}-\mathrm{Cl}$ stretch vibration band at near $310 \mathrm{~cm}^{-1}$ showed a less pronounced change in $80 \mathrm{~min}$ compared to that in $\mathrm{CrCl}_{3}$ /[BMIM]Cl/glucose (Fig. 4(a)). Evidently, replacement of $\mathrm{Pt}-\mathrm{Cl}$ bond by $\mathrm{Pt}-\mathrm{O}$ bond is not favored as indicated by the FIR spectra. As a result, $\mathrm{PtCl}_{2}$ displays rather low catalytic activity for glucose conversion (Fig. 3). In the $\mathrm{FeCl}_{3} /[\mathrm{BMIM}] \mathrm{Cl} /$ glucose system, the absorbance of the anion 
$\left[\mathrm{FeCl}_{4}\right]^{-}$at $381 \mathrm{~cm}^{-1}$ decreased sharply and the absorbance of $\left[\mathrm{FeCl}_{4}\right]^{2-}[36]$ at near $280 \mathrm{~cm}^{-1}$ increased gradually at the same time. Neither the absorbance at $381 \mathrm{~cm}^{-1}$ or $280 \mathrm{~cm}^{-1}$ was restored, even after $2 \mathrm{~h}$ (Fig. 4(d)). Evidently the strong Fe-O bonds contribute to the non-selective catalytic performance of Fe(III) catalyst due to the formation of dominantly humins.

\subsection{In situ FIR study of the interaction strength between substrate and catalytic center}

FIR spectroscopy was also applied to the study the coordination strength of metal chloride $\mathrm{CrCl}_{3}$ in [BMIM]Cl in the presence of model compounds with different oxygen sources. The results were correlated with the performance of $\mathrm{CrCl}_{3}$ for glucose conversion in the presence of the same model compounds [10].

The $\mathrm{Cr}-\mathrm{Cl}$ bond in $\left[\mathrm{CrCl}_{6}\right]^{3-}$ complex absorbs at $302 \mathrm{~cm}^{-1}$. The intensity of this band decreased in response to the added model compounds, $n$-butanol (Fig. 6(a)), cyclohexanone (Fig. 6(b)), $\mathrm{H}_{2} \mathrm{O}$ (Fig. 6(c)). The intensities of these bands were able to gradually restore by evaporization of the model compound at $100{ }^{\circ} \mathrm{C}$. The coordination to $\mathrm{Cr}$ (III) by the oxygens from $n$-butanol, cyclohexanone, or water is so weak that a temperature of $100{ }^{\circ} \mathrm{C}$ was sufficient to disrupt the $\mathrm{Cr}-\mathrm{O}_{\text {model compound }}$ coordination bond and to reverse fully to the stable $\left[\mathrm{CrCl}_{6}\right]^{3-}$ complex. However, when excess glycolaldehyde was added to

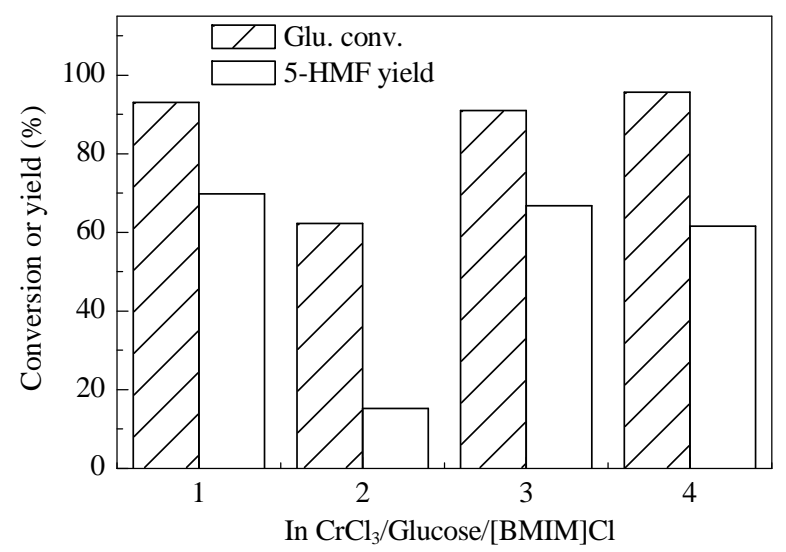

Fig. 7. The effect of different probing model compounds on glucose conversion. (1) None; (2) Glycolaldehyde; (3) $n$-Butanol; (4) Cyclohexanone. Reproduced with permission from Ref. [10].

the $\mathrm{CrCl}_{3} /[\mathrm{BMIM}] \mathrm{Cl}$ system, the $\mathrm{Cr}-\mathrm{Cl}$ bond absorbance at 302 $\mathrm{cm}^{-1}$ was decreased by nearly $1 / 2$ (Fig. 6(d)), due to the formation of $\mathrm{Cr}-\mathrm{O}$ (coming from glycolaldehyde) coordination bonds and $\mathrm{Cr}-\mathrm{Cl}-\mathrm{Cr}$ bridged bond [36]. Thus $\mathrm{Cr}$ (III) center is strongly coordinated with glycolaldehyde. And the strong interaction with the glycoaldehyde competes with glucose coordination to the $\mathrm{Cr}(\mathrm{III})$, resulted in a reduced glucose conversion and 5-HMF yield, as supported by the catalytic results in Fig. 7.
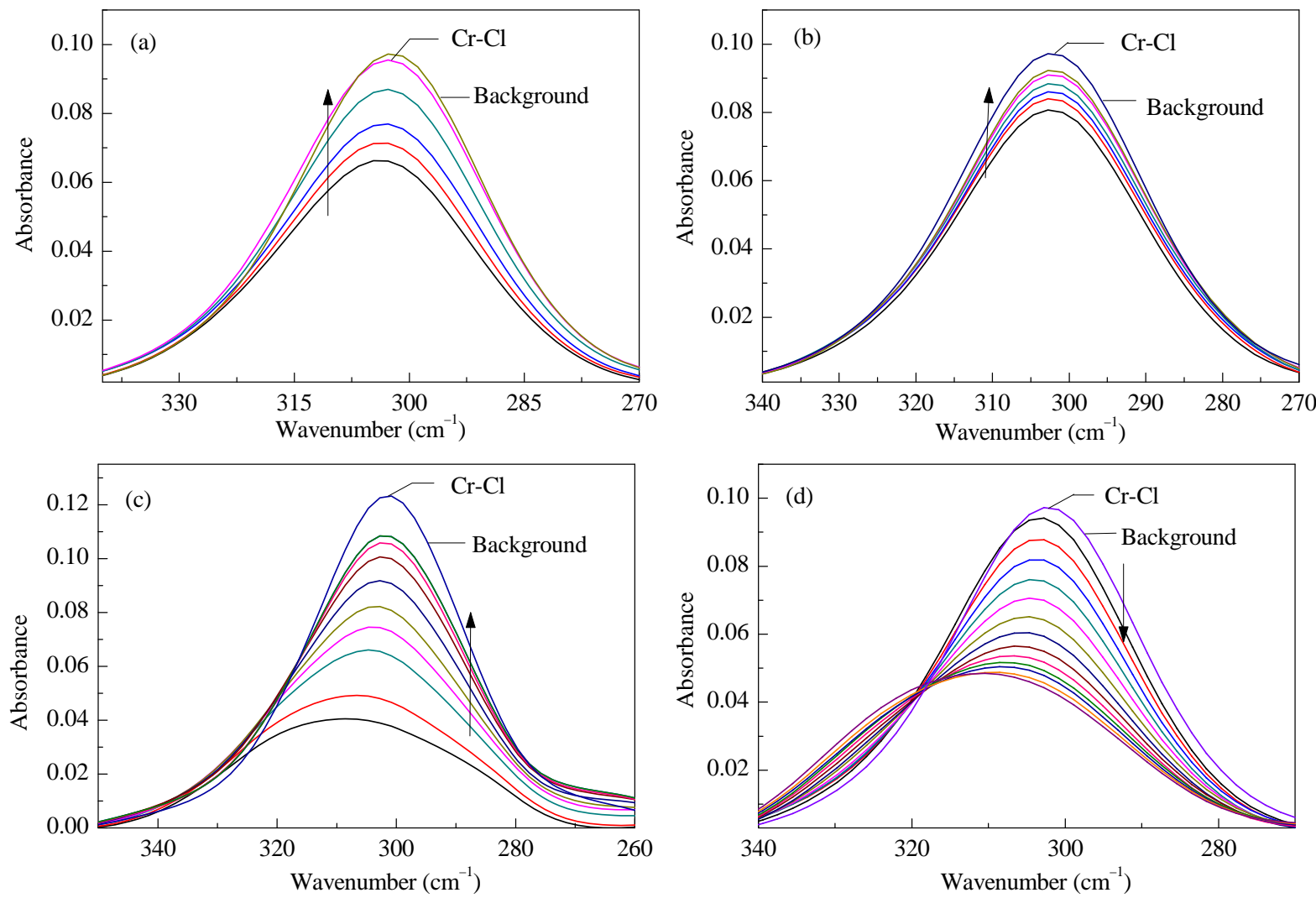

Fig. 6. (a) FIR spectra of the $\mathrm{Cr}-\mathrm{Cl}$ stretch vibration in the $\mathrm{CrCl}_{3} /[\mathrm{BMIM}] \mathrm{Cl} / n$-butanol system; (b) FIR spectra of the $\mathrm{Cr}-\mathrm{Cl}$ stretch vibration in the $\mathrm{CrCl}_{3} /[\mathrm{BMIM}] \mathrm{Cl} /$ cyclohexanone system; (c) FIR spectra of the $\mathrm{Cr}-\mathrm{Cl}$ stretch vibration in the $\mathrm{CrCl}_{3} /[\mathrm{BMIM}] \mathrm{Cl} /$ water system. (d) FIR spectra of the $\mathrm{Cr}-\mathrm{Cl}$ stretch vibration in the $\mathrm{CrCl}_{3} /[\mathrm{BMIM}] \mathrm{Cl} /$ glycolaldehyde system. The FIR spectra were recorded at $80^{\circ} \mathrm{C}$; the arrows in (a), (b) and (c) represent the variation trend of the $\mathrm{Cr}-\mathrm{Cl}$ coordination bond during evaporation of the model compound. The background spectra of $\mathrm{CrCl}_{3} /[\mathrm{BMIM}] \mathrm{Cl}$ system were taken before the addition of the model compound. Reproduced with permission from Ref. [10]. 


\section{Conclusion and prospect}

FIR spectroscopy is shown to be a convenient technique broadly applicable to characterize the catalyst structure, the process of gas adsorption on catalyst surface, and the determination of metal ions by using a probe molecule such as CO. The in-situ FIR technique is particularly suited to follow the progress of catalyst evolution and the products in catalytic reactions. The lattice vibration energies of metal clusters and metal oxides catalysts lie in FIR region, as well as the vibration energy of coordination complex catalysts. The force between adsorbent and adsorbate is typically weak so that it falls in the low energy mode within the FIR region. Furthermore, in-situ FIR spectroscopy could also track the changes of homogeneous catalyst in the course of catalytic reaction and explore the coordination strength between reagent and catalytic center. FIR spectroscopy could complement the application of MIR, NIR spectroscopy with the advantage of capable of measuring these low energy vibration modes accurately. In addition, there are various low energy vibration modes, such as hydrogen bonding, framework vibration of aromatics, and the rotation of the gas molecules. Thus FIR has a much far-reaching potentials in the study of catalysts and catalytic mechanisms. We expect much progress can be made by devoting efforts in expanding the potential scope and applications in the characterization of catalysts and in the mechanism study of catalytic processes.

\section{Z. Conrad Zhang}

State Key Laboratory of Catalysis, Dalian National Laboratory for Clean Energy, Dalian Institute of Chemical Physics, Chinese Academy of Sciences, Dalian 116023, Liaoning, China

Tel: +86-411-84379462

Fax: +86-411-84379462

E-mail: zczhang@yahoo.com

Received 29 February 2016

Accepted 19 March 2016

Published 5 May 2016

DOI: $10.1016 /$ S1872-2067(15)61087-7

\section{References}

[1] T. Lear, R. Marshall, J. A. Lopez-Sanchez, S. D. Jackson, T. M. Klapotke, M. Baumer, G. Rupprechter, H. J. Freund, D. Lennon, J. Chem. Phys., 2005, 123, 174706/1-174706/13.

[2] L. MacAleese, P. Maitre, Mass Spectrom. Rev., 2007, 26, 583-605.

[3] Z. Z. Wu, E. B. Xu, J. Long, Y. J. Zhang, F. Wang, X. M. Xu, Z. Y. Jin, A. Q. Jiao, Food Control, 2015, 50, 405-412.

[4] J. Lejeune, J. B. Brubach, P. Roy, A. Bleuzen, C. R. Chim., 2014, 17, 534-540.

[5] S. Nasrazadani, T. Springfield, Mater. Struct., 2013, 47, 16071615.

[6] T. C. Ruthenburg, P. C. Perlin, V. Liu, C. E. McDade, A. M. Dillner, Atmos. Environ., 2014, 86, 47-57.

[7] S. Vahur, A. Teearu, I. Leito, Spectrochim. Acta A, 2010, 75, 1061-1072.

[8] M. Zhang, T. Moxon, Am. Miner., 2014, 99, 671-680.

[9] M. D. Hopkins, V. M. Miskowski, P. M. Killough, A. P. Sattelberger, W. H. Woodruff, H. B. Gray, Inorg. Chem., 1992, 31, 5368-5374.

[10] H. X. Li, W. J. Xu, T. Y. Huang, S. Y Jia, Z. W. Xu, P. F. Yan, X. M. Liu, Z. C. Zhang, ACS Catal., 2014, 4, 4446-4454.

[11] F. Keilmann, Infrared Phys., 1991, 31, 373-380.

[12] K. Ohno, T. Shimoaka, N. Akai, Y. Katsumoto, J. Phys. Chem. A, 2008, $112,7342-7348$.

[13] S. Huant, J. B. Robert, G. Chouteau, P. Bernier, C. Fabre, A. Rassat, Phys. Rev. Lett., 1992, 69, 2666-2669.

[14] E. A. Pidko, V. Degirmenci, R. A. van Santen, E. J. M. Hensen, Inorg. Chem., 2010, 49, 10081-10091.

[15] J. H. Baek, J. S. Kim, M. J. Moon, M. S. Lee, J. Nanosci. Nanotechnol., 2015, 15, 5314-5317.

[16] M. J. Taylor, A. L. Odell, H. A. Raethel, Spectrochim. Acta, 1968, 24, 1855-1861.

[17] E. Lasseuguette, A. Gandini, M. N. Belgacem, H. J. Timpe, Polymer, 2005, 46, 5476-5483.

[18] P. M. Boorman, A. J. Carry, Inorg. Nucl. Chem. Lett., 1968, 4, 101-105.

[19] A. Fielicke, G. von Helden, G. Meijer, Eur. Phys. J. D, 2005, 34, 83-88.

[20] C. Ratsch, A. Fielicke, A. Kirilyuk, J. Behler, G. von Helden, G. Meijer, M. Scheffler, J. Chem. Phys., 2005, 122, 124302/1-124302/15.

[21] A. Fielicke, C. Ratsch, G. von Helden, G. Meijer, J. Chem. Phys., 2007,

\section{Graphical Abstract}

Chin. J. Catal., 2016, 37: 637-643 doi: 10.1016/S1872-2067(15)61087-7

\section{Far reaching potentials of far infrared spectroscopy in catalysis research}

Huixiang Li, Z. Conrad Zhang*

Dalian Institute of Chemical Physics, Chinese Academy of Sciences; University of Chinese Academy of Sciences

Far infrared spectroscopy complements the application of mid-infrared, near-infrared spectroscopy with the advantage of capable of measuring these typical lower energy vibration modes accurately.

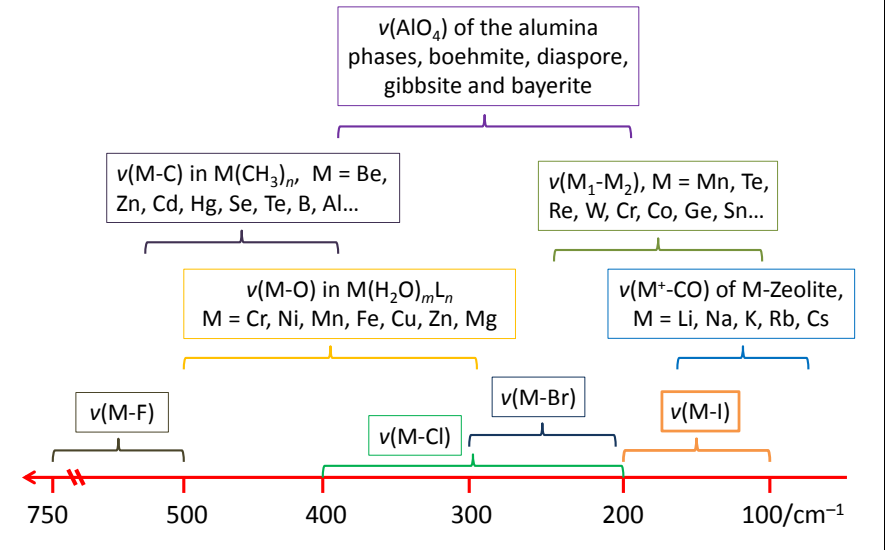


$127,234306 / 1-234306 / 8$.

[22] H. D. Ruan, R. L. Frost, J. T. Kloprogge, L. Duong, Spectrochim. Acta, 2002, 58, 265-272.

[23] F. Windisch Jr., J. Appl. Phys., 2004, 95, 5435-5442.

[24] J. Pellicer-Porres, A. Segura, Ch. Ferrer-Roca, J. A. Sans, P. Dumas, Phys. Conden. Matt., 2013, 25, 50592/1-50592/7.

[25] J. C. Lavalley, Catal. Today, 1996, 27, 377-401.

[26] C. Otero Arean, G. Turnes Palomino, A. Zecchina, G. Spoto, S. Bordiga, P. Roy, Phys. Chem. Chem. Phys., 1999, 1, 4139-4140.

[27] J. Saussey, T. Rais, J. C. Lavalley, Bull. Soc. Chim. Fr., 1985, 305-312.

[28] U. Engström, R. Ryberg, J. Chem. Phys., 2000, 112, 1959-1965.

[29] Z. C. Zhang, Wiley Interdisciplinary Rev.: Energy Environ., 2013, 2, 655-672.

[30] R. J. van Putten, J. C. van der Waal, E. de Jong, C. B. Rasrendra, H. J.
Heeres, J. G. de Vries, Chem. Rev., 2013, 113, 1499-1597.

[31] E. A. Pidko, V. Degirmenci, R. A. van Santen, E. J. M. Hensen, Angew. Chem. Int. Ed., 2010, 49, 2530-2534.

[32] J. Guan, Q. Cao, X. C. Guo, X. D. Mu, Comput. Theor. Chem., 2011, 963, 453-462.

[33] R. W. Nagorski, J. P. Richard, J. Am. Chem. Soc., 2001, 123, 794-802.

[34] H. B. Zhao, J. E. Holladay, H. Brown, Z. C. Zhang, Science, 2007, 316, 1597-1600.

[35] S. P. Weng, Fourier Transform Infrared Spectrometry, 2nd ed., Chemical Industry Press, Beijing, 2012, 12.

[36] J. S. Avery, C. D. Burbridge, D. M. Goodgame, Spectrochim. Acta A, 1968, 24, 1721-1726.

[37] Y. M. Zhang, E. A. M. Pidko, E. J. Hensen, Chem. Eur. J., 2011, 17, 5281-5288.

\title{
远红外光谱在催化领域的应用前景
}

\author{
李会香 ${ }^{\mathrm{a}, \mathrm{b}}$, 张宗超 ${ }^{\mathrm{a}, *}$ \\ a中国科学院大连化学物理研究所, 催化基础国家重点实验室, 洁净能源国家实验室(筹), 辽宁大连 116023 \\ b中国科学院大学, 北京100049
}

摘要: 中红外光谱是催化领域的重要技术之一, 已被广泛应用于催化过程的研究, 而远红外光谱 (FIR) 的应用相对而言并 不成熟. FIR 可用于分析催化过程中较低能量的振动模式, 如氢键、芳烃骨架振动、重原子间的伸缩振动、气体分子的转 动等, 从而可弥补中红外光谱的应用. 在本文中, 我们综述了有关 FIR 在催化领域的应用, FIR 可以用来表征金属有机化合 物类、金属原子簇类、不同晶相的氧化铝等催化剂的结构. 在研究气体在催化剂表面上的吸附过程中 FIR 展现出独特的 优势: 直接检测到气体 (如 $\mathrm{CO}$ ) 与不同类型载体 (如 $\mathrm{MO}_{x}$ ) 的成键 $\mathrm{M}-\mathrm{C}$, 分析两者的相互作用强度, 进而表征催化剂载体表 面的性质. 如 CO 在载体 M-ZSM-5 (M $=\mathrm{Li}, \mathrm{Na}, \mathrm{K}, \mathrm{Rb}, \mathrm{Cs})$ 上的吸附强度 $v(\mathrm{M}-\mathrm{C})$ 和交换离子 $\mathrm{M}$ 的 $1 / r^{2}$ 成正比 $(r$ 是 $\mathrm{M}$ 的 半径), 且 $\mathrm{CO}$ 在 $\mathrm{ZnO}$ 上的吸附强度 $\left(v(\mathrm{Zn}-\mathrm{C})=215 \mathrm{~cm}^{-1}\right)$ 相对于在 M-ZSM-5 的吸附较强 $\left(v(\mathrm{M}-\mathrm{C})=85-150 \mathrm{~cm}^{-1}\right)$, 因 $\mathrm{ZnO}$ 载体的电负性较碱金属强, 对于 CO 的吸附作用更强. 另外原位 FIR 可通过分析金属物与多种底物的相互作用强度、反应 过程中催化剂的结构、浓度的变化趋势等, 为催化机理的分析提供理论支持. 在最新的研究成果中, 我们借助原位远红外 光谱研究了多种金属氯化物催化葡萄糖异构化过程的机理, 经分析得知活性最高的催化剂 $\mathrm{CrCl}_{3}$ 与底物葡萄糖分子中的羰 基、羟基、乙二醇等结构配位较弱, 而与葡萄糖分子中的活性部位羟基乙醛结构作用较强. 而其他的金属氯化物如 $\mathrm{VCl}_{3}$ 和 $\mathrm{FeCl}_{3}$ 不仅与羟基乙醛结构配位较强, 与底物和产物分子中的羰基或羟基的作用也较强, 这对于其选择性地异构化葡萄糖 不利. 综上所述远红外光谱在催化领域的应用展现了广阔的前景, 我们期待远红外光谱在催化研究中得到更广泛的运用.

关键词: 催化; 远红外光谱; 表征; 原位分析; 低能振动模式

收稿日期: 2016-02-29. 接受日期: 2016-03-19. 出版日期: 2016-05-05.

*通讯联系人. 电话/传真: (0411)84379462; 电子信箱: zczhang@yahoo.com

基金来源: 国家千人计划; 中国科学院国家外国专家局创新团队国际合作伙伴计划.

本文的英文电子版由Elsevier出版社在ScienceDirect上出版(http://www.sciencedirect.com/science/journal/18722067). 